\title{
4 Innovation in Early Music Festivals
}

\author{
Domains, Strategies and \\ Outcomes
}

\author{
Elena Castro-Martínez, Albert Recasens and \\ Ignacio Fernández-de-Lucio
}

\section{Introduction and objectives}

Innovation has been described as a strategic activity involving companies and, more recently, administrations and other social entities (OECDEUROSTAT, 2018), which contributes to both competitiveness and to social progress in areas such as employment, the environment and health. This justifies the interests of governments in promoting them. In 1934, the economist Joseph Alois Schumpeter laid the foundations for an understanding of the effects of innovation on the development of companies and the economic systems in which they operate (Schumpeter, 1934). However, it was not until the early 1990s (OECD, 1992) that the study of innovation and innovation processes began to be promoted. This triggered the development of innovation policies in OECD member countries and the realization that innovation could provide various kinds of benefits to innovative companies and have highly relevant social effects. Early innovation studies focused on industry, but gradually extended to include other sectors, including the cultural sector.

From an innovation perspective, the cultural sector is complex. First, it combines manufacturing (graphic arts, musical instruments) with different kinds of services (publishing, cinematography, video and television programmes, sound recording, libraries and museums, artistic creations, the performing arts). Second, it includes a range of different sized companies, public entities, private non-profit institutions and individual artists, and other service professionals such as restorers and cultural guides. Third, the cultural sector depends heavily on public resources, either through ownership of entities that are part of the sector (e.g., museums, theatres, concert halls, libraries, archives, festivals, etc.) or because many of the sector's private actors (musicians, music festivals, etc.), rely on public aid to conduct their activities (Baumol and Bowen, 1965).

A case study of knowledge transfer and exchange in the field of musicology (Castro-Martínez, Recasens and Jiménez-Sáez, 2013) shows the importance of innovation for early music festivals and the dissemination of 
previously unknown musical heritage. The absence of studies on innovations in early music festivals prompted a deeper and broader study, designed to contribute to a better understanding of both innovation and its relationship with musicology research in the context of early music festivals. The aim of this chapter is to describe the in-depth analysis developed to learn about innovation in a very traditional type of festivals (those dedicated to early music) and identify the types of innovation implemented, the strategies employed by festival managers to create these innovations, as well as the benefits that early music festivals derive from these innovation efforts, helping them to carry out their main traditional mission (dissemination of musical heritage). To do it, a survey on innovation activities, strategies and the results derived from these activities in early music festivals was developed in collaboration with early music festival directors. To ensure robust and comparable results, the 58 member festivals of the European network of early music festivals (REMA - Réseau Européen de Musique Ancienne), the only early music network in Europe, were surveyed and answered by more than $40 \%$ of the respondents.

\section{Literature review}

Several authors (Miles and Green, 2008; Stoneman, 2010) have suggested that, due to its differences with industrial and other services innovation, the innovation process related to the creative industries requires particular and detailed investigation. Innovation in the cultural sector has been analysed in terms of specific subsectors, such as art restoration (Lazzeretti, 2003), music (Wilson and Stokes, 2005; Castro-Martínez, Recasens and JiménezSaez, 2013), archaeology companies (Parga-Dans, Castro-Martínez and Fernández de Lucio, 2012), book publishing (Benghozi and Salvador, 2016) and museums (Li and Ghirardi, 2019).

Several studies examine the interactions and innovation networks in different sectors (e.g., Asheim et al., 2007; Martin, 2013) and differentiate among the different sources of knowledge for innovation depending on the respective sector's knowledge base (analytical, synthetic and symbolic). These works focus on one of the so-called 'symbolic sectors', as a cultural sector, and conclude that since the activities in these sectors are often developed within a project framework, interactions differ from project to project. It is suggested that this generates intensive activity, which, in principle, involves local actors or actors from the same region with the same cultural affinities (Martin, 2013). However, in a study of the video game industry (Chaminade, Martin and McKeever, 2021), the authors suggest that knowledge exchange networks are both regional and global, although they serve different purposes and use different mechanisms.

A particular creative industry case is cultural festivals (music, cinema, etc.), which are classified as events and, due to their singularity, are analysed from the perspectives of their management (Getz, 2008), the degree 
of uncertainty (Rüling and Strandgaard Pedersen, 2010) and their social impact (Del Barrio, Devesa and Herrero, 2012). The professionalization of events, particularly cultural events such as arts festivals, began in the mid20 th century. The literature includes several case studies of innovations related to festivals, focusing on different genres (Mackellar, 2006; Hjalager, 2009), using different approaches (Orosa-Paleo and Wijnberg, 2008; Larson, 2009) and aimed at different objectives (Carlsen et al., 2010). Arts festivals have some common characteristics, including the need for management of a highly artistic product that is time-bound and has a well-defined purpose (Rolfe, 1992). Mackellar (2006) uses Schumpeter's (1942) categories of product, process, organization, marketing, services and social aspects to examine innovations related to a regional festival held in Australia. MacKellar (2006) analyses the actors involved according to their actor type (social/business) and their mutual interactions, and shows that the breadth and depth of the resulting innovations are the result of network interactions and the strength (frequency and duration) of these exchanges.

Orosa-Paleo and Wijnberg (2008) proposed a new approach to determine the innovativeness of a specific festival held in the Netherlands, based on calculating a referent innovativeness index according to the number of new performers, and a classification innovativeness index related to the number of different musical genres included in the festival. The authors compared the values of these indices for the same festival held in two consecutive years. They identified differences indicating whether the innovativeness of the festival had increased or decreased from one year to the next.

Hjalager (2009) uses an innovation system approach to perform a detailed analysis of the different actors involved in a contemporary music festival, held in Denmark (Roskilde Festival), and the direct and indirect relationships established among the actors. She identifies different types of innovations that emerged during the development of the festival and several spin-offs that were created around the festival which offer different types of products and services.

Larson (2009) conducted a case study of three festivals held in Sweden. He considers festivals as inter-organizational networks, in which the different stakeholders (festival organizers, audience, host city, sector, restaurants, volunteers, the media) contribute to the development of advances in various product, process, marketing, organization and social aspects. He found that the importance given to innovativeness varied across festival organizers and that other stakeholders involved in the complex festival organization network play relevant roles in the innovation process. As festival organization becomes more professional, other planned, more institutionalized processes emerge, including market research which provides information to assess audiences' experiences and develop new products.

Carlsen et al. (2010) analyse innovation and failure management strategies in the context of three cultural festivals in the UK, Norway and Sweden. They examine the value chain and identify the stakeholders and 
various elements that contribute to festival success or failure. The authors conclude that partners and networks are essential for innovativeness and that failures can occur simultaneously with the introduction of innovations. They suggest that festival managers should try to identify success and failure cycles in order to prevent future failures.

One area where the identification of innovation is particularly complex is the arts. In this field, it is difficult to separate the originality of a performance from its innovativeness. For instance, Castañer and Campos (2002) claim that the generally accepted definition of innovation (the first offer by a company of a new or differentiated product or service) does not apply to the arts sector and that an artistic innovation can take the form of the programming of a work that is new to the field (Castañer and Campos, 2002, p. 32). Gohoungodji (2020) analyses three Canadian music festivals and suggests that artistic innovation is a process that involves numerous stakeholders, who sometimes collaborate over the production of a new artistic good, for example, related to staging. However, he also provides a detailed list of the different types of innovations that may emerge in this setting. Drawing on work on the innovation strategies implemented in festivals, Calvo-Soraluce and Viñals-Blanco (2014) studied the effect of social media on innovation. They found that social media can contribute to new product development and marketing and can transform the festival experience. In a review of the literature on innovation in music industry processes, Saragih, Simatupang and Sunitiyoso (2018) show the importance of interactions with various types of stakeholders in co-innovation and open and collaborative innovation processes, but do not delve into the diversity of possible strategies. Along similar lines, a study of knowledge transfer and exchange processes in an early music context (Castro-Martínez, Recasens and Jiménez-Sáez, 2013) shows that early music festivals are relevant as promoters of content innovations, which arise from the interactions among diverse stakeholders (musicologists, early music performers, producers and specialized and exigent audiences).

All of the above works are based on case studies and focus mostly on contemporary pop/urban music festivals. However, they add to our understanding of the different aspects of innovation in the context of festivals (domains, types, interactions, actors and other stakeholders, barriers).

This chapter focuses on early music festivals, which have some organizational, production and commercial aspects in common with other music festivals, but which have some specific aspects, such as links to heritage sites and relationships with music education and musicology research centres.

\section{Context}

The term 'early music' is generally used to describe music composed before 1800 , although it can refer, also, to how this music is performed. It led to what is known as the 'Early Music Movement' (Butt, 2002). Musicology 
research goes beyond the publication of results in books and journals and includes the transfer of new knowledge to music performers. The revival of early music has resulted in the organization of specialized festivals, currently numbering more than 300, mainly in Europe, and the existence of a specialized circuit. The success of these events has had a significant impact on music programming, with early music becoming increasingly more relevant. Alongside the integration of early music in mainstream music cycles, the sector has undergone a process of professionalization through the integration of organizational, funding and marketing systems from other sectors.

The different artistic ensemble models can be distinguished by type (from chamber groups and consorts, to choirs and orchestras); composition (regular members, guest soloists, ad hoc participation of different performers); function (occasional, stable administrative facility, reduced office) and funding (public/private, travel or production aid, structural grants from related institutions). There seems to be significant variability between ensembles from southern or peripheral Europe and those from countries with strong cultural policies (François, 2005). Early music festivals almost inevitably involve musicians from several different countries, which leads to intensive mobility of musicians across different continents.

The entities involved in the organization of early music festivals in Europe coalesced to form REMA, the European Early Music Network. REMA currently includes 122 active organizations, based in 22 European countries, involved in the production of early music festivals and concert series. REMA membership includes festivals (76), ensembles, orchestras, professionals and some festival networks (European Festivals Association and Nordic Early Music Federation, Irish Early Music Network). France accounts for the highest number members (25), followed by Italy (18), Belgium (9) and Germany, Spain and the UK (7). REMA works with other European cultural platforms to promote networking activity, publication of research and performance of joint projects.

\section{Conceptual framework and methodology}

The study analyses three aspects related to innovation processes: first, innovation types, second, the strategies and stakeholders involved in achieving them and, third, the benefits deriving from the innovative effort.

The innovation types are based on those defined by Schumpeter (1942), which underpin innovation surveys (OECD-EUROSTAT, 2005), but extending the conventional set of business domains (production, marketing, organization) to include services related specifically to the creative industries. Miles and Green (2008) used the term 'hidden innovation' to describe innovations that, in their opinion, were excluded from current measures of innovation and were linked, in particular, to the cultural industries. They proposed a conceptual creative industries innovation framework to allow a 
precise and structured view of the various cultural industry areas where innovation is likely to emerge. Their conceptual framework has been applied in work on managing cultural innovation and cultural policy (Brandellero and Kloosterman, 2010; Jaw, Chen and Chen, 2012).

Miles and Green's (2008, pp. 65-67) conceptual framework categorizes creative industry innovations according to five main culture-related process domains: general management and funding activities; production and pre-production; communication; product and user experience. They identify 15 potential innovation sites within these five domains and their corresponding interfaces: (1) general administrative activities and financial management; (2) business model; (3) value chain location and positioning; (4) communication with suppliers and partners; (5) internal communication; (6) back-office/backstage production processes; (7) transactions; (8) marketing and customer relationship management; (9) product content; (10) performance and production processes; (11) product format; (12) product delivery; (13) user/product interface; (14) user interactions and (15) user capabilities.

In relation to strategies, the innovation literature suggests that innovators implement one or a combination of three basic strategies (Vega-Jurado et al., 2008): innovation based on their own resources and capabilities ('making'); innovation enabled by acquiring or renting knowledge, equipment or materials from a third party ('buying') and innovation facilitated by cooperation with some other entity ('cooperating'). All three strategies and their respective stakeholders are included in the model developed to analyse innovation in festivals.

The outcomes or benefits of innovation can be grouped into four areas (OECD-EUROSTAT, 2005, p. 79): competition, demand and markets; production and delivery; workplace organization and other (relations, economy, society) which can be adapted to the cultural industries value chain.

Since we considered that the concepts and terms related to innovation might be unfamiliar to festival managers, the initial questionnaire that was developed for this study contained an exhaustive list of potential innovations in each area, the strategies and actors involved and the possible expected benefits. The draft questionnaire was discussed with the directors of three internationally recognized early music festivals in Spain and was revised based on their suggestions. The resulting draft was discussed with members of the REMA executive committee, whose suggestions related to other possible innovations helped to refine it further. The proposed project was presented at a REMA general meeting (June 2013) where we asked REMA members for their agreement to participate in the survey.

The questionnaire asked about innovation areas, strategies and benefits and was organized in several sections, as follows:

1 General data on the festival: name, web site, start year, calendar of events, periodicity, mailing address and contact person. 
2 Information related to the most recent festival (number of concerts, budget and funding sources, personnel), links between the festival and other initiatives in the region/town, membership of festival networks and participation in their activities.

3 Context: availability of financial resources, spaces, personnel and other information and services required for the festival organization.

4 Innovation types in main domains and their interfaces (see detail in Appendix 1).

5 Innovation strategies and the stakeholders involved, according to the taxonomy proposed by Vega-Jurado et al. (2008).

6 The results of innovative activities and the kinds of benefits obtained.

In the sections that asked about innovation types, respondents were given a list of possible innovations and could indicate all that applied. Questions about proposed innovations referred to the previous three years and respondents could choose among three answers: (1) YES, (2) NO and (3) Introduced before the reference period. There was space to add other innovations not included in the list provided; none of the respondents added any. In the section on benefits, the proposed list was based on the benefits identified in the OECD-EUROSTAT Oslo Manual (2005), adapted to festivals. The analysis was based on counting the numbers of times the proposed alternatives were chosen.

The survey was administered online in two rounds - in September 2013 and January 2015. The preliminary results (2013) were presented at a REMA annual meeting held in autumn 2014. The second round of the survey received more responses - some from festivals that had not responded to the first round and some which modified previous responses and corrected errors.

\section{Results and discussion}

\section{General information}

From the 58 festival organizers in 19 countries who were invited to respond to the questionnaire, 28 directors from 12 countries agreed to participate, but 4 failed to complete the innovation section and were dropped from the analysis. We achieved a response rate of over $40 \%$ was obtained which included a wide representation of countries. All the festival directors involved authorized use of individualized data. Appendix 2 provides a list of the festivals that provided completed questionnaires.

The festivals exhibit several differences related to their longevity (birthdates ranging from 1920 to 2010), budget (ranging from $€ 42,000$ to $€ 2.5$ million) and number of concerts (ranging from 6 to 150). In terms of funding, on average, $65 \%$ of total revenue comes from regional and local public entities, $17 \%$ from ticket sales and the remainder from a mix of cultural 
associations, private sponsors and festival merchandising (recordings), programmes and advertising. All of the festivals were held annually - in spring $(26 \%)$, summer $(37 \%)$ or autumn $(26 \%)$ (some festivals also programme concerts for the winter months) - and lasted around a week to ten days. Certain festivals are specific to particular cities and, although a few are held in European capitals (Copenhagen, Stockholm, Ljubljana), most are located in smaller cities and towns - often with an important historical heritage. Most concerts are held in historic buildings (churches or palaces), which offer more suitable acoustics for early music, which was conceived for such spaces. However, some festivals prefer modern music halls that allow larger seating capacity (higher income). Some festivals are multi-site, that is, they include concerts held in different locations in a given geographical area; for example, the Utrecht festival involves over 20 cities in the Netherlands and Belgium and the Úbeda and Baeza Festival includes concerts held in both of these towns and another eight nearby small towns.

The festivals are organized as non-profit cultural charities (42\%), nonprofit non-governmental organizations (NGO) (29\%), private entities $(17 \%)$ and public entities $(13 \%)$. Festival managers reported that organizing bodies had remained the same for several years and no other organizational innovations were identified. The organizational structures of these festivals tend to be limited; they involve full-time annual employment of one to five employees (mean 1.5) and part-time employment of between one and seven employees per year (mean 1.8 and mode 1). During the time that the festival runs, another 1-40 individuals are employed (mean 7). Two of the festivals (Haute Jura and Ribeauville) have no paid staff; they are run solely by volunteers who have been members of the organizing cultural charity for more than 40 years. Similar to popular music festivals, volunteers are recruited to work at early music festivals directly via the web, posters and job boards or through local entities such as cultural associations, universities and city halls. Although volunteers are important for the development of the festivals, they are not as numerous as in popular music festivals (mean for early music festivals is around 15).

Regarding funding sources, most festivals are funded from a variety of sources: ticket sales, local, regional and national grants, cultural associations, private sponsors, advertising, sales of recordings of previous concerts and sales of other cultural products, with large differences among festivals in the proportions of each of these sources of revenue. Only four reported a single source (public funding). None of the festivals reported using crowdfunding and none stated that they had included a new source of funding in recent years; no innovations in funding mechanisms were identified.

Given the importance of context for the development of innovations, festival organizers were asked about the availability of appropriate conditions, professionals, knowledge and the services required to organize the festival. Most organizers responded that there was good availability of all these aspects and many claimed to have sufficient musicology research resources, 
which is a singular aspect of early music festivals. Only one festival, Gregynog, which is held in 'a remote rural area of Wales' (according to the respondent), reported difficulties related to getting access to large musical instruments and availability of specialists in the local area to tune old instrument; the organizers were required to hire in this expertise - usually from London.

\section{Innovation areas}

We grouped the identified innovations in two broad groups: (a) preproduction, production and product; and (b) commercialization, communication and marketing.

\section{Production, pre-production and product}

Most festivals are themed: the theme or motto might commemorate the birth or death of a composer or poet, or be related to a local historical event, and is intended to increase the attractiveness of the festival to the public. Less than half of the festivals considered sponsors' interests or local preferences, which is evidence of their considerable autonomy.

For most festivals, the participation of new and foreign artists was not an innovation, nor was the performance of music never performed in modern times or new approaches to the interpretation of well-known compositions, or the re-reading of known pieces because such offerings are part of their essence and the interests of their most loyal audience. This highlights the importance of links with universities and musicology research centres and relations with other early music festivals and cultural entities. Regarding contents, some directors stressed the need for the programmes to contain works and performers well known to the loyal audience year after year, i.e. to combine innovation with tradition, as this loyal audience expects their familiar or favourite pieces as well as known interpreters.

Some festivals organize parallel activities that provide opportunities for young musicians or are used to present awards. To increase their audiences, many $(67 \%)$ of festivals provide educational concerts or performances aimed specifically at children, dance shows and other forms of artistic expression. They also offer lectures, discussions and films about the lives of contemporary composers, musical instrument workshops and courses for new performers. These parallel activities are aimed at providing audiences with a better understanding of early music and the range of activities is designed to attract a more diverse audience.

A few festivals referred to staging innovations, related to the use of lighting, audiovisual resources or props or sensory experiences to submerge the audience in the atmosphere of the period, the context or the ceremony for which the piece was conceived; $50 \%-60 \%$ of festivals have never introduced such innovations and perform the concerts in a traditional way and 


\section{Elena Castro-Martinez et al.}

in the same venues year after year, usually churches and other buildings that constitute the historical heritage of the cities in which they are held. However, more than $60 \%$ of festivals had offered concerts in new venues in the previous three years, including newly restored or newly discovered historical or artistic spaces and 'contemporary' spaces such as science museums, gardens, shopping malls or bars and natural areas that might attract younger audiences. Also, a few festivals had organized concerts at unusual times (midnight or in the morning), in conjunction with special shows, for example, outdoor shows for children, or innovative use of the physical space such as mats rather than conventional audience seating.

New product formats include live simultaneous broadcasting of concerts outside the concert venue. Two festivals project shows on screens outside the venue or in cinemas, 5 had installed screens in historic or artistic buildings with adequate acoustic conditions to allow a satisfactory experience, 11 festivals offer live broadcasting on the radio and 12 festivals provide live streaming on the web. The live streaming had been confined to particular days, for example, 21 March, which is the European Day of Early Music, and involved only selected parts of past concerts. Half of the festivals offered digital products (CDs, DVDs) related to their past concerts; none offered MP3 formats. Product format innovations fall into the product delivery and user interface category and are highly dependent on the festival budget. Artists are paid according to the media employed to distribute their performances; in other words, they receive royalty payments if the concert is recorded for sale or public dissemination. All but one of the respondents indicated that budgetary constraints were a determinant of programme contents and said, also, that the media rarely paid copyright application fees.

To complement the festival concerts and, thus, enrich their content, festivals have introduced new parallel activities, such as meetings with the artists, conferences, dinners, talks, workshops, awards ceremonies and presentations of new recordings. The first two were the most frequent; the others apply to only a few festivals.

Due to the small numbers of recordings available from niche local or national producers, more than half of the festivals allowed different record companies to sell their recordings in festival shops to allow festival audiences to buy recordings by artists they are interested in, although recorded elsewhere. This was considered to make a significant contribution to the dissemination of early music.

\section{Commercialization, communication and marketing}

Commercialization, communication and marketing innovations were identified in terms of ticket prices, discounts and sales outlets, and the mechanisms used to interact with audiences and to publicize the festival's activities. 
Innovations in ticket pricing for regular audiences included packages providing entry to several concerts or the whole festival, packages combining festival concerts with other cultural activities and packages that include concerts in other festivals and hotel accommodation. Most festivals offered the first two types (66\%), but only a few offered deals that included other activities or other festivals and hotel accommodation which imply coordination with other entities. The small numbers of staff involved in early music festivals makes such coordination difficult and consequently sales are carried out by traditional mechanisms.

Most festivals offer special rates for young people aged under 18 and for students. Only a few offered discounts for pensioners, unemployed people, large families, groups, education centres or groups at risk of exclusion. Regarding ticket sales and cancellations, none of the respondents reported development of smartphone apps for ticket sales and cancellations were possible only in three festivals.

Nine festivals reported some type of customer loyalty schemes based on identification systems for regular customers, 11 declared no loyalty scheme and 4 did not answer. The benefits of the schemes that were offered were advance booking, reserved seating, discounted tickets and a newsletter providing details of forthcoming events.

Fewer than half of the festivals provide advance information on planned activities or advance ticket sales, via email. Most festivals interact with users via phone, email and Facebook; a few use social media, such as Twitter, SMS or MMS, or online forums or blogs. The scarce use of many of these means is again due to the need for additional specialized staff which are unaffordable for these festivals.

Ten festivals had conducted audience satisfaction surveys to identify potential improvements. The York festival had been administering such surveys since 1986; the others since 2005. Some conducted annual surveys, others conducted them every two or three years.

Most festivals engage in a range of intensive activities to publicize their festival programmes (via the festival website, a local website, local press, radio and TV channels, journals, classical music radio stations). However, early music is poorly represented on national general-interest TV channels and classical music TV shows, confirming that it remains a minority genre. Finally, very few festivals offer smartphone information applications.

The results of our survey show that almost all the festivals had introduced some commercial or communication innovations, the most radical related to very large festivals (Utrecht and Göttingen) and very small festivals with limited budgets (Úbeda and Baeza, the International Bach chamber music festival, the Copenhagen Renaissance Music Festival, the Wunderkammer and the Day of Early Music in Alden Biesen). It seems that the capacity to innovate in these areas depends not just on financial capabilities but also and perhaps more so on the creativity and commitment of managers and volunteers. 


\section{Innovation strategies}

The festivals identified the strategies used to achieve the innovations described above, specifically, making, using their own means $(64 \%)$, buying from companies $(10 \%)$ and cooperating with other entities $(27 \%)$. In contrast to innovation in other sectors, buying is not the main strategy except in the case of technological communication innovations.

The respondents identified 26 types of stakeholders, including festival associations belonging to REMA, artists, research centres, music schools, local and regional governments (tourism and cultural actors), sponsors, materials and equipment suppliers, volunteers and general and specialized music media. Depending on the type of innovation, the festivals interacted with all of these stakeholders.

Some innovations are related to festival content (new artists, revivals, new approaches to the performance of well-known works) and are based mostly on own resources, although some were achieved in collaboration with early music festival networks, artists, research centres and music schools. Several festivals had links to local research institutes and music schools. Collaborations with early music networks and artists, universities and music schools involve international and local actors, which is in line with the findings in Martin and Moodysson (2011) for moving media (TV production, digital arts and design, development of computer games software, etc.).

Innovations in production and staging, such as use of audiovisual material, new sound designs, new lighting or unconventional venues, tend to be in collaboration with equipment suppliers and local authorities. Introducing festival audiences to a different experience often involves other local culture and tourism actors.

Marketing and communication innovations tend to involve universities and music schools, local and specialized media and volunteers with social media skills.

\section{Innovation outcomes}

Festival managers identified the following as possible benefits of the innovations implemented: larger and more diversified audiences, increased ticket sales/revenue, new festival sponsors, larger amounts of sponsorship, increased involvement of local and new stakeholders in the development of the festival, reduced production and organization costs and improved prestige and enhanced public image of the festival.

In the case of almost all the festivals, innovative efforts resulted in larger and more diversified audiences and, therefore, higher ticket revenue and greater visibility and prestige. A small number of festivals had achieved reduced costs or gained new sponsors.

The questionnaire asked which of the suggested benefits had been achieved and their importance (high, moderate, low). The responses showed that the benefits were considered to be mostly moderate (46\%) or high $(35 \%)$. 
Greater visibility and prestige increase the profits from early music festivals. Larger and more diversified audiences guarantee the future of early music festivals, despite their niche status. The innovations introduced are allowing early music festivals to be seen as important cultural events, with significant impact on their host cities and regions, and as relevant platforms for international cultural cooperation.

\section{Conclusions}

This study contributes to current knowledge on innovation in the creative industries by shedding light on innovation types, strategies and benefits in the context of early music festivals, a sort of cultural festival, which usually take place in historical places, aimed at generally local and specialized audiences. This is the first in-depth study of innovation in this context and has provided the expected better understanding of the areas of innovation, strategies and outcomes achieved in this kind of cultural festivals. Methodologically, the study demonstrates the importance of identifying these activities to allow festival managers to appreciate their capacity for innovation.

Preliminary work with festival directors to identify potential innovation areas and possible innovations, allowed the design of a questionnaire that helped directors to conceptualize, reflect and structure their innovative activities, which they had been doing intuitively, and could be applied to other cultural festivals.

Based on our sample, early music festivals develop different types of innovations and also use different innovation strategies, most notably cooperation with other stakeholders. In terms of product and production, the festivals combine innovation with tradition, as most loyal audiences are familiar with early music and, along with interesting novelties in content, performance or staging, they expect to hear their familiar or favourite pieces. Regarding the outcomes of the innovative effort, festival directors were aware that their innovations had led to improvements, the most intangible being increased prestige and the most tangible being bigger and more diversified audiences. However, they were aware, also, that these innovations had not translated into reduced production or organizational costs or involvement of new stakeholders or sponsors.

Almost all respondents had introduced some of the possible innovations identified for each innovation area, but there were differences among them. Innovative capacity related to these festivals does not depend on budget or the numbers of people involved as staff or volunteers; both the largest festivals and those with very small budgets reported high numbers of innovations. It seems that innovations depend on the creativity and amount of effort expended by the individuals involved in the festival organization, but this is an aspect that was not addressed in the questionnaire and would require further research.

The results of this study show that content related product innovations (e.g., premieres of recently discovered compositions or pieces not performed 
in modern times), depend heavily on musicology research and music performances, that is, on research in the humanities, and the festivals' links to musicology research and interpretation schools. This is similar to Pavitt's (1984) science-based sectors, which depend on new knowledge, and complements the findings in Zukauskaite (2012) that universities contribute to innovation through joint competence building, changes to market concepts and new social corporate responsibility actions.

This study has two main limitations. On the one hand, the sample of respondents, although representative of the population studied, is small. On the other, festival managers were unable to specify whether their innovative activities had been aimed only at their respective event or included all early music festivals. This is not surprising since they have not previously been asked to reflect in detail on this dimension of their activities. It would be interesting to know to what extent the innovations identified had occurred in other types of classical music festivals and, especially, whether those innovations not identified for early music festivals (general administrative activities and financial management, business model, value chain location and positioning, communication with suppliers and partners, internal communication and transactions) applied to other cultural festivals.

\section{Acknowledgements}

The authors are grateful to the European Early Music Network (REMA) and the festival organizers who agreed to respond to the questionnaire. We are especially grateful to Peter Pontvik and Helena de Winter, chairman and executive secretary of REMA when the survey was conducted, who enthusiastically involved themselves in the project. We acknowledge helpful contributions on questionnaire design and piloting from the directors of three Spanish early music festivals: Esperanza Asiain (Estella), Javier Marín (Úbeda y Baeza) and Alberto Martín (Pórtico de Zamora).

The authors would like to thank two anonymous reviewers for their constructive comments.

A preliminary version of this article was presented and discussed at the 15th International Conference on Arts and Cultural Management (AIMAC), held in Ca' Foscari University of Venice, Italy, June 23-26, 2019.

\section{References}

Asheim, B., Coenen, L., Moodysson, J. and Vang, J. (2007) 'Constructing knowledge-based regional advantage: Implications for regional innovation policy', Int. J. Entrepreneurship and Innovation Management, 7(2-5), pp. $140-155$.

Baumol, W. and Bowen, W. (1965) 'On the performing arts: The anatomy of their problems', The American Economic Review, Papers and Proceedings, 55, pp. 495-502. 
Benghozi, P.-J. and Salvador, E. (2016) 'How and where the R\&D takes place in creative industries? Digital investment strategies of the book publishing sector', Technology Analysis \& Strategic Management, 28(5), pp. 568-582. https://doi. org/10.1080/09537325.2015.1122184

Brandellero, A.M.C. and Kloosterman, R.C. (2010) 'Keeping the market at bay: Exploring the loci of innovation in the cultural industries', Creative Industries Journal, 3(1), pp. 61-77. https://doi.org/10.1386/cij.3.1.61_1

Butt, J. (2002) Playing with History: The Historical Approach to Musical Performance. Cambridge-New York: Cambridge University Press. https://doi. org/10.1017/CBO9780511613555

Calvo-Soraluce, J. and Viñals-Blanco, A. (2014) 'Stimulating attendees' leisure experience at music festivals: Innovative strategies and managerial processes', Global Journal of Management and Business Research: F Real Estate Event \& Tourism Management, 14(2), pp. 38-52.

Carlsen, J., Andersson, T.D., Ali-Knight, J., Jaefer, K. and Taylor, R. (2010) 'Festival management innovation and failure', International Journal of Event and Festival Management, 1(2), pp. 120-131. https://doi.org/10.1108/17852951011056900

Castañer, X., and Campos, L. (2002) 'The determinants of artistic innovation: Bringing in the role of organizations', Journal of Cultural Economics, 26, pp. 29-52. https://doi.org/10.1023/A:1013386413465

Castro-Martínez, E., Recasens, A. and Jiménez-Sáez, F. (2013) 'Innovation systems in motion: An early music case', Management Decision, 51(6), pp. 1276-1292. https://doi.org/10.1108/MD-11-2011-0433

Chaminade, C., Martin, R. and McKeever, J. (2021) 'When regional meets global: Exploring the nature of global innovation networks in the video game industry in Southern Sweden', Entrepreneurship \& Regional Development, 33(1-2), pp. 131-146. https://doi.org/10.1080/08985626.2020.1736184

Del Barrio, M.J., Devesa, M. and Herrero, L.C. (2012) 'Evaluating intangible cultural heritage: The case of cultural festivals', City, Culture and Society, 3(4), pp. 235-244. https://doi.org/10.1016/j.ccs.2012.09.002

François, P. (2005) Le monde de la musique ancienne. Sociologie économique d'une innovation esthétique. Paris: Economica.

Getz, D. (2008) 'Event tourism: Definition, evolution, and research', Tourism Management, 29(3), pp. 403-428. https://doi.org/10.1016/j.tourman.2007.07.017

Gohoungodji, P. (2020) 'How do artists innovate on scene? Understand the implementation of artistic innovation through three Canadian music festivals', International Journal of Strategic Management, 20(1), pp. 67-78. https://dx.doi. org/10.18374/IJSM-20-1.7

Hjalager, A-M. (2009) 'Cultural tourism innovation systems. The Roskilde festival', Scandinavian Journal of Hospitality and Tourism, 9(2-3), pp. 266-287. https://doi.org/10.1080/15022250903034406

Jaw, Y-L. Chen, Ch-L. and Chen, S. (2012) 'Managing innovation in the creative industries - A cultural production', Innovation: Management, Policy \& Practice, 14(2), pp. 256-275. https://doi.org/10.5172/impp.2012.14.2.256

Larson, M. (2009) 'Festival innovation: Complex and dynamic network interaction', Scandinavian Journal of Hospitality and Tourism, 9(2-3), pp. 288-307. https://doi.org/10.1080/15022250903175506

Lazzeretti, L. (2003) 'City of art as a high culture local system and cultural districtualization processes: The cluster of art restoration in Florence', International 
Journal of Urban and Regional Research, 27(3), pp. 635-648. https://doi. org/10.1111/1468-2427.00470

Li, C. and Ghirardi, S. (2019) 'The role of collaboration in innovation at cultural and creative organisations. The case of the museum', Museum Management and Curatorship, 34(3), pp. 273-289. https://doi.org/10.1080/09647775.2018. 1520142

Mackellar, J. (2006) 'An integrated view of innovation emerging from a regional festival', International Journal of Event Management Research, 2(1), pp. 37-47.

Martin, R. and Moodysson, J. (2011) 'Innovation in symbolic industries: The geography and organization of knowledge sourcing', European Planning Studies, 19(7), pp. 1183-1203. https://doi.org/10.1080/09654313.2011.573131

Martin, R. (2013) 'Differentiated knowledge bases and the nature of innovation networks', European Planning Studies, 21(9), pp. 1418-1436. https://doi.org/10. 1080/09654313.2012.755836

Miles, I. and Green, L. (2008) Hidden Innovation in the Creative Industries. http:// www.nesta.org.uk/publications (accessed 10 September 2020).

OECD (1992) Technology and the Economy. The Key Relationships. Paris: OCDE.

OECD-EUROSTAT (2005) Oslo Manual. Guidelines for Collecting, Reporting and Using Data on Innovation, 3rd, The Measurement of Scientific, Technological and Innovation Activities. Paris/Luxemburg: OECD Publishing/ Eurostat.

OECD-EUROSTAT (2018) Oslo Manual 2018: Guidelines for Collecting, Reporting and Using Data on Innovation, $4^{a}$ ed., The Measurement of Scientific, Technological and Innovation Activities, Paris/Luxemburg: OECD Publishing/ Eurostat.

Orosa-Paleo, I. and Wijnberg, N.M. (2008) 'Organizational output innovativeness: A theoretical exploration, illustrated by a case of a popular music festival', Creativity and Innovation Management, 17(1), pp. 3-13. https://doi. org/10.1111/j.1467-8691.2007.00463.x

Parga-Dans, E., Castro-Martínez, E. and Fernández de Lucio, I. (2012) 'La arqueología comercial en España: ¿un sistema sectorial de innovación?’, Cuadernos de Gestión, 12(1), pp. 139-156.

Pavitt, K. (1984) 'Sectoral patterns of technical change', Research Policy, 13(6), pp. 343-373. https://doi.org/10.1016/0048-7333(84)90018-0

Rolfe, H. (1992) Arts Festivals in the UK. London: Policy Studies Institute.

Rüling, C.C. and Strandgaard Pedersen, J. (2010) 'Film festival research from an organizational studies perspective', Scandinavian Journal of Management, 26(3), pp. 318-323. https://doi.org/10.1016/j.scaman.2010.06.006

Saragih, H.S., Simatupang, T.M. and Sunitiyoso, Y. (2018) 'Multi-actor innovation in the music industry: A state-of-the-art review', International Journal of Innovation Science, 10(4), pp. 430-453. https://doi.org/10.1108/IJIS-07-2017-0065

Schumpeter, J.A. (1934) The Theory of Economic Development. Cambridge, MA: Harvard University Press.

Schumpeter, J. (1942) Capitalism, Socialism and Democracy. New York: Harper. Stoneman, P. (2010) Soft Innovation: Changes in Product Aesthetics and Aesthetic Products. New York: Oxford University Press Inc. https://doi. org/10.1002/9781118739044.ch4

Vega-Jurado, J., Gutiérrez-Gracia, A., Fernández de Lucio, I. and ManjarrésHenríquez, L. (2008) 'The effect of external and internal factors on firms' product 
innovation', Research Policy, 37(4), pp. 616-632. https://doi.org/10.1016/j. respol.2008.01.001

Wilson, N.C. and Stokes, D. (2005) 'Managing creativity and innovation. The challenge for cultural entrepreneurs', Journal of Small Business and Enterprise Development, 12(3), pp. 366-378. https://doi.org/10.1108/14626000510612286

Zukauskaite, E. (2012) 'Innovation in cultural industries: The role of university links', Innovation, 14(3), pp. 404-415. https://doi.org/10.5172/ impp.2012.14.3.404 


\section{Appendix 4.1 \\ Innovations proposed in the questionnaire}

For all questions, the possible answers were: Yes (implemented in the last three years), No and Yes, but it was already available or had been done before.

1 Organization and funding:

1.1 Legal status: Public entity, Private entity, Non-profit cultural association, Non-profit Non-Governmental Organization, Publicprivate consortium, Other (specify)

1.2 Funding sources: Tickets, Public sponsors (Local, Regional, National, European Union, Cultural associations, Private sponsors, Advertising, Crowdfunding, Other resources)

2 Pre-production, production and product

2.1 Content of product: New performers, Established foreign performers, Premiere of pieces of music not performed in modern times, New approaches to the performance of known musical compositions, Re-reading of known pieces of music, New staging, New contextualization (atmosphere of the time, visual projections during the concert, religious choreographed piece of music and in other context, etc.), Educational concerts, Presentation of the program/instruments, Dance and other forms of artistic expression, Others (specify)

2.2 Performance and production processes:

2.2.1 New illumination, New sound, Use of audio-visuals, Others (specify)

2.2.2 Are the concerts offered online or in an alternative place? New spaces, On line (streaming), Cinemas, Screens in alternative places, Others (specify)

\subsection{Product format and delivery of product}

2.3.1 Offer of digital products associated with past or present concerts: CD, DVD, MP3/FLAC, Radio, TV, Dissemination through YouTube, Vimeo or other managers of audiovisual contents, Own channel of radio or TV, Others (specify) 
2.3.2 Collaboration with record companies or distributors to sell CD or DVD during the festival

2.3.3 Parallel activities: Meetings with artists, Conferences, Midday meals, Colloquiums, Awards for the artists, Workshops, Presentations of CD, Others

3 Commercialization, communication and advertising

3.1 Prices and bookings: Ticket packages for several concerts, Ticket packages for the whole festival, Combined ticket packages for concerts and other cultural activities, Combined ticket packages for other festivals, Tourist packages (Ticket + hotel packages or similar), Others (specify). Special rates: Under the age of 18 years, Students, Pensioners, Unemployed, Large families, Groups, Educational centres, Groups at risk of exclusion, Others (specify). Audience loyalty system.

3.2 Sales points: Points of sale in advance, Telephone, Internet, Smartphone app, Option to cancel, Others (specify)

3.3 Mechanisms to facilitate user-festival organizer interactions: e-mail, Facebook, Twitter, SMS or MMS, Internet forum, Blog, Others (specify). Audience satisfaction survey.

3.4 Festival advertisement media: Festival website, Web of the City Hall, Local press, Local radio stations, Local TV channels, National press, National radio stations, National TV channels, Press agencies, Specialized music journals, Radio (classical music programs), TV (classical music shows), Facebook, Twitter, Smartphone apps, Newsletter. 


\section{Appendix 4.2 \\ Responding early music festivals}

\begin{tabular}{|c|c|c|c|c|}
\hline Name & Country & $\begin{array}{l}\text { Starting } \\
\text { date }\end{array}$ & Type of entity & $\begin{array}{l}\text { No. of } \\
\text { concerts }\end{array}$ \\
\hline $\begin{array}{l}\text { Musica vzw-Impulscentrum Domein } \\
\text { Dommelhof }\end{array}$ & $\mathrm{BE}$ & 1973 & $\mathrm{NGO}$ & 37 \\
\hline Muziekcentrum De Bijloke (Gent) & $\mathrm{BE}$ & 2000 & Public & 150 \\
\hline Händel Festival de Halle & $\mathrm{DE}$ & 1920 & NGO & 46 \\
\hline International Händel Festival Göttingen & $\mathrm{DE}$ & 1922 & Private & 40 \\
\hline Copenhagen Renaissance Music Festival & DK & 2006 & Private & 15 \\
\hline Musica Antigua Aranjuez & ES & 1994 & Private & 8 \\
\hline $\begin{array}{l}\text { Festival de Música Antigua de Úbeda y } \\
\text { Baeza }\end{array}$ & ES & 1997 & Public & 28 \\
\hline Semana de Música Antigua de Estella & ES & 1967 & Public & 15 \\
\hline BRQ Vantaa & FI & 2010 & NGO & 13 \\
\hline Festival D’Ambronay & FR & 1980 & $\begin{array}{l}\text { Cultural } \\
\text { Charity }\end{array}$ & 30 \\
\hline $\begin{array}{l}\text { Festival de Musique Ancienne de } \\
\text { Ribeauvillé }\end{array}$ & FR & 1984 & $\begin{array}{l}\text { Cultural } \\
\text { Charity }\end{array}$ & 9 \\
\hline Festival de Musique de Haut Jura & FR & 1978 & $\begin{array}{l}\text { Cultural } \\
\text { Charity }\end{array}$ & 10 \\
\hline $\begin{array}{l}\text { Grandezze \& Meraviglie, Festival } \\
\text { Musicale Estense }\end{array}$ & IT & 1998 & $\begin{array}{l}\text { Cultural } \\
\text { Charity }\end{array}$ & 16 \\
\hline Pavia Barocca & IT & 2000 & $\begin{array}{l}\text { Cultural } \\
\text { Charity }\end{array}$ & 23 \\
\hline Festival Antiqua (Bolzano) & IT & 1991 & $\mathrm{NGO}$ & 7 \\
\hline Festival Echi Lontani & IT & 1994 & NGO & 21 \\
\hline Wunderkammer & IT & 2006 & NGO & 12 \\
\hline Festival Monteverdi & IT & 1983 & Private & 10 \\
\hline $\begin{array}{l}\text { International Bach chamber music } \\
\text { festival }\end{array}$ & LV & 2001 & $\begin{array}{l}\text { Cultural } \\
\text { Charity }\end{array}$ & 6 \\
\hline Utrecht Early Music Festival & NL & 1981 & $\begin{array}{l}\text { Cultural } \\
\text { Charity }\end{array}$ & 146 \\
\hline À Volta do Barroco & PT & 2006 & NGO & 8 \\
\hline Stockholm Early Music Festival & SE & 2002 & $\begin{array}{l}\text { Cultural } \\
\text { Charity }\end{array}$ & 15 \\
\hline Gregynog Festival & UK & 1933 & $\begin{array}{l}\text { Cultural } \\
\text { Charity }\end{array}$ & 17 \\
\hline York Early Music Festival & UK & 1977 & $\begin{array}{l}\text { Cultural } \\
\text { Charity }\end{array}$ & 21 \\
\hline
\end{tabular}

Source: Own elaboration from the survey about innovation in REMA early music festivals. Note: In type of entity, NGO means Non-profit Non-Governmental Organization. 